\title{
SUPPORT PAYMENTS FOR AGRICULTURE AND RURAL DEVELOPMENT IN LATVIA
}

\author{
Irina Pilvere $^{1}$, Aleksejs Nipers ${ }^{1}$, Aija Pilvere-Javorska ${ }^{2}$ \\ ${ }^{1}$ Latvia University of Agriculture \\ ${ }^{2}$ Baltic Advisory Ltd, Latvia \\ Irina.Pilvere@1lu.lv; Aleksejs.Nipers@1lu.lv; Apilvere@gmail.com
}

\begin{abstract}
The European Union (EU) Common Agricultural Policy (CAP) affects the development of the agricultural industry and rural areas in all the Member States. A very important role is played by various support payments as one of the policy instruments. The CAP has been developing and is being reformed; therefore, it is important to assess the effect of various CAP support instruments on the development of the agricultural industry. Therefore, the research aim is to assess the support instruments and kinds of support as well as their effects on selected agricultural indicators. The research study proceeds in three stages or phases: first, the identification of the total amount of support payments paid and the key kinds of support; second, a detailed analysis of the key kinds of support; third, the identification of associations between the amounts of support payments and other agricultural and farm performance indicators. The research found that in the period 2005 - 2014 in Latvia, the total amount of support amounted to EUR 4.3 billion, of which EUR 520 million or $12 \%$ were received by approximately 1000 FADN farms. The most significant kinds of financial support in Latvia were direct payments, accounting for $47 \%$ of the total amount of support and financial assistance provided for rural development with $39 \%$. The total amount of financial support and the amount of area-based payments affected the key agricultural indicators as well.
\end{abstract}

Key words: support payments, kinds of support payments, indicators.

\section{Introduction}

Until the early nineties of the last century, the CAP was mainly oriented to support markets. Prices were guaranteed and complemented by export subsidies and import restrictions. Agricultural production was stimulated through guaranteed prices, and farm incomes depended on output prices and quantities. Over the last two decades, the CAP was reformed four times, mainly to shift support from production and prices to direct income supports (Fragoso et al., 2011). Since the Agenda 2000 reforms, the CAP has been characterised as having two 'pillars' through which funding is disbursed. Pillar I provides subsidies to farmers and accounts for about $90 \%$ of the overall budget (Lowe, Buller, \&Ward, 2002). The CAP's second 'pillar' is rural development. Introduced in 1999, the second pillar consolidated numerous funding measures for only about $10 \%$ of total CAP expenditure (Watts et al., 2009). M. Raggi, L. Sardonini and Viaggi D. (2013) stress that the current CAP payments are important for staying in/exiting farming activities. In 2013, a new Common Agricultural Policy was defined after several years of negotiations between the EU Commission, the Member States, the EU Parliament and the Council of Ministers (Burnya \&Terrones Gavira, 2015). For this reason, it is necessary to assess the performance of the CAP's support instruments in the previous period. In Latvia, farmers have to take into consideration the eligibility criteria set by the CAP since 2004 . For these reasons, the research aim is to assess the support instruments and kinds of support as well as their effects on selected agricultural indicators in Latvia. To achieve the aim, three specific research tasks were set: 1) to examine the support instruments and the key kinds of financial support in Latvia; 2) to perform a detailed analysis of the key kinds of financial support in Latvia; 3 ) to identify causal relationships between the amounts of support payments and other agricultural and farm performance indicators.

The object of the research is support instruments for FADN farms.

\section{Materials and Methods}

Analysis, synthesis and logical construction, as well as a statistical analysis method - correlation analysis - were employed to perform the research tasks. The present research analysed information and data of the Central Statistical Bureau (CSB) and the Rural Support Service (RSS). The research design process used special and general literature, methodological materials on the EU financial support for agriculture and rural development etc. The Farm Accountancy Data Network (FADN) was exploited to identify the effect of support payments on the economy of farms in Latvia. The FADN is a European system of sample surveys conducted every year to collect accountancy data from farms with the aim of monitoring the income and business activities of EU agricultural holdings. Moreover, the FADN is an important informative source for understanding the impact of the measures taken under the CAP on different types of agricultural holdings (European Commissions, 2017). A FADN farm sample includes not less than 1000 farms in order to ensure a representative sample of farms in Latvia (LR Zemkopības ministrija, 2017). 


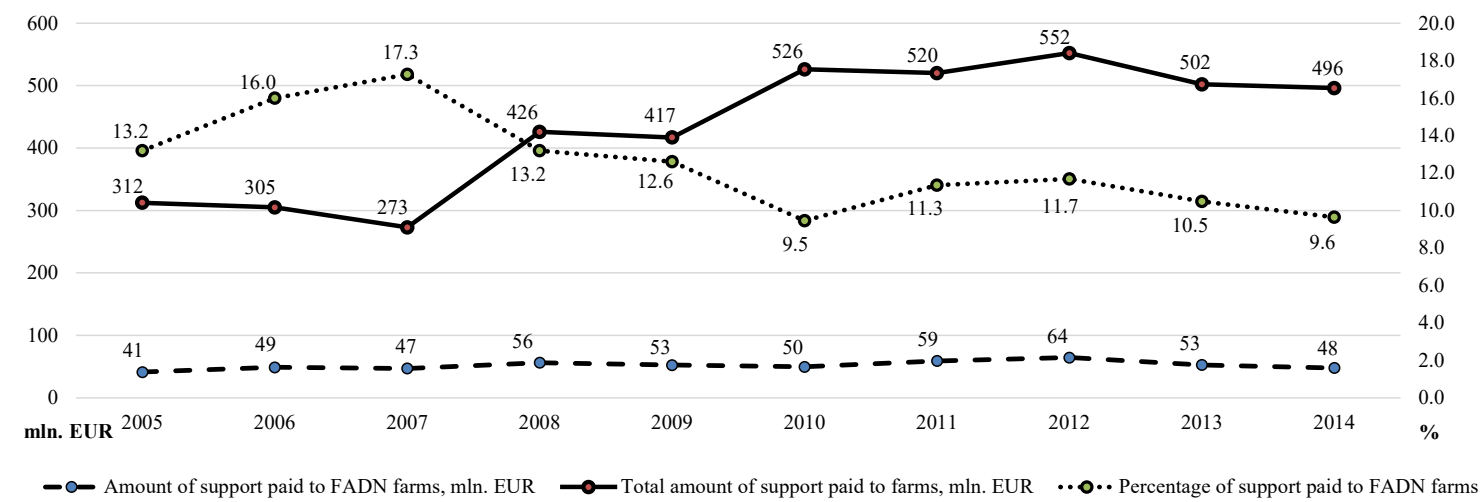

Source: authors' calculations based on based on Datu bāze ... (2016); Lauku atbalsta dienests (2016a, 2016b).

Figure 1. Total amount of support paid to farms, the amount of support paid to FADN farms, mln. EUR, and the percentage of support paid to FADN farms in Latvia in the period $2005-2014$.

\section{Results and Discussion}

1. Characteristics of support payments for agriculture and rural development in Latvia

The economic performance indicators of FADN farms were affected by support payments in Latvia in the time period $2005-2014$. In the period of analysis, the total amount of support paid to FADN farms reached almost EUR 519.5 million, which comprised on average $12 \%$ of the total amount of financial support paid in this period - EUR 4329.5 million (Figure 1).

A comparison of change in the amount of support in the period 2005 - 2014 reveals that it increased by $59 \%$ in the country as a whole, while an increase for FADN farms was relatively steady - the increase was only $17 \%$. In 2013, the FADN summarised data on 1000 farms (LVAEI, 2014), which accounted for $1.2 \%$ of the total number of farms in the country. In 2005, 932 farms (LVAEI, 2014) or $0.7 \%$ of the total farms were included in the FADN. In the period of analysis, the total number of farms decreased in absolute terms by 51208 (CSB, 2016a; 2016b) or $38.5 \%$ in relative terms. This indicates that the performance of FADN farms was better than the performance of the entire agricultural industry, as $1.2 \%$ of the farms received $10.5 \%$ of the total amount of support paid in the country in 2013.

The financial support paid may be classified into three main groups:

1. (EU and national) direct payments, which include the Single Area Payment Scheme (SAPS), complementary national direct payments (CNDP) that are called transitional national support since 2013, and various special support schemes that have been introduced to support agriculture CAP Pillar 1. Until 15 October 2006, their source of finance was the guarantee section of the European Agricultural Guidance and Guarantee Fund (EAGGF), while after this date the source of finance for SAPS and special schemes was the European Agricultural Guarantee Fund (EAGF) and CNDP were funded from the government budget.

2. Support payments for rural development or CAP Pillar 2, which consisted of SAPARD funding and the funding of the Structural Funds (SF) for the period $2004-2006$, were funded from the

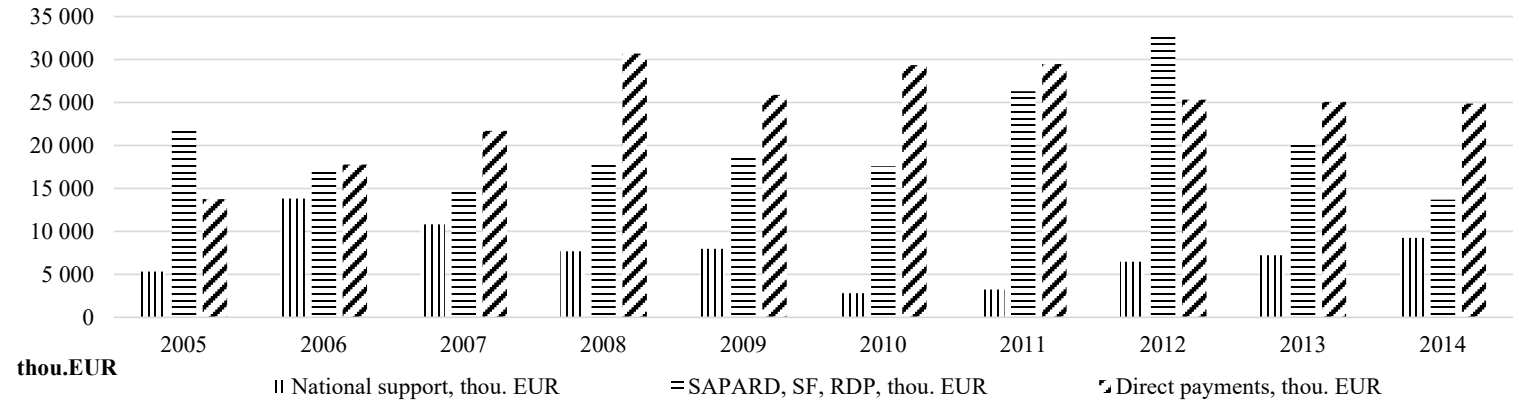

Source: authors' calculations based on Datu bāze ... (2016).

Figure 2. Distribution of financial support paid to FADN farms in Latvia in the period 2005 - 2014, thou. EUR. 
guidance section of the European Agricultural Guidance and Guarantee Fund (EAGGF), the national government budget, the allocations for the Rural Development Plan 2004 - 2006 (funded from the guarantee section of the EAGGF and the national government budget) and the Rural Development Programme 2007 - 2013 (RDP 2007 - 2013) (funded from the European Agricultural Fund for Rural Development (EAFRD) and the government budget).

3. National support payments (national subsidies); the source of finance is the government budget.

The distribution of financial support paid to FADN farms in the period 2005 - 2014 was as follows: 1) direct payments - EUR 244 million or $47 \%$ of the total;
2) support for rural development - EUR 201 million or $39 \%$; 3) national subsidies - EUR 75 million or $14 \%$. The distribution of financial support for every year is shown in Figure 2. The amount of direct payments paid to FADN farms steadily increased in the beginning of the period - until 2008, while after that it stabilised at EUR 25-29 million annually. The amount of support for rural development depends on the financial phase of the period - at the beginning of the period the amount is smaller, in the middle of the period it increases, but at the end of the period the amount decreases. In contrast, the amount of national financial support consistently decreased, which is understandable, as national funding is required both for paying direct payments and for co-funding rural development projects.

Table 1

Percentage distribution of direct payments, the total amount of which exceeded EUR 500 thou. by kind of support for FADN farms in Latvia in the period $2005-2014$

\begin{tabular}{|c|c|c|c|c|c|c|c|c|c|c|c|}
\hline Indicators & 2005 & 2006 & 2007 & 2008 & 2009 & 2010 & 2011 & 2012 & 2013 & 2014 & Total \\
\hline Total & 100.0 & 100.0 & 100.0 & 100.0 & 100.0 & 100.0 & 100.0 & 100.0 & 100.0 & 100.0 & 100.0 \\
\hline SAPS payments & 34.6 & 32.9 & 32.7 & 28.9 & 42.5 & 44.5 & 49.3 & 58.4 & 64.0 & 64.8 & 45.6 \\
\hline $\begin{array}{l}\text { Decoupled CNDP for areas (since } \\
\text { 2007) }\end{array}$ & 10.4 & 17.5 & 20.7 & 13.5 & 15.1 & 12.7 & 11.2 & 11.7 & 11.1 & 7.0 & 12.9 \\
\hline $\begin{array}{l}\text { Special support for milk } \\
\text { production }\end{array}$ & 48.9 & 35.3 & 18.1 & 11.8 & 13.9 & 0.0 & 0.0 & 0.0 & 0.0 & 0.0 & 9.9 \\
\hline $\begin{array}{l}\text { Stubble field in the winter period } \\
\text { (since 2008) }\end{array}$ & 0.0 & 0.0 & 12.6 & 10.2 & 14.2 & 11.6 & 10.8 & 8.7 & 6.4 & 4.9 & 8.6 \\
\hline $\begin{array}{l}\text { CNDP for slaughtered or } \\
\text { exported cattle }\end{array}$ & 0.0 & 0.0 & 0.0 & 0.0 & 0.0 & 15.0 & 11.1 & 10.9 & 11.1 & 8.5 & 6.2 \\
\hline School fruits & 0.0 & 8.2 & 7.8 & 5.4 & 6.3 & 4.2 & 2.6 & 2.0 & 2.1 & 0.0 & 3.9 \\
\hline $\begin{array}{l}\text { Decoupled CNDP for milk sold } \\
\text { within the limit of the quota }\end{array}$ & 0.0 & 0.0 & 0.0 & 0.0 & 0.0 & 4.7 & 4.5 & 4.6 & 4.5 & 5.5 & 2.6 \\
\hline $\begin{array}{l}\text { Decoupled CNDP for areas under } \\
\text { field crops (since 2010) }\end{array}$ & 0.0 & 0.0 & 0.0 & 17.5 & 0.0 & 0.0 & 0.0 & 0.0 & 0.0 & 0.0 & 2.2 \\
\hline $\begin{array}{l}\text { Restructuring of the sugar } \\
\text { industry }\end{array}$ & 1.0 & 1.4 & 1.5 & 1.5 & 2.4 & 2.5 & 2.2 & 2.1 & 1.9 & 1.3 & 1.8 \\
\hline $\begin{array}{l}\text { Decoupled CNDP for slaughtered } \\
\text { or exported cattle (since 2007) }\end{array}$ & 0.0 & 0.0 & 0.0 & 0.6 & 0.8 & 0.9 & 3.2 & 3.8 & 3.5 & 3.5 & 1.8 \\
\hline $\begin{array}{l}\text { Diversification support for sugar } \\
\text { beet producers }\end{array}$ & 0.0 & 0.0 & 3.4 & 2.3 & 2.7 & 2.4 & 0.0 & 2.3 & 0.2 & 1.6 & 1.6 \\
\hline $\begin{array}{l}\text { EU direct payments }+ \text { CNDP> } \\
\text { EUR } 5000\end{array}$ & 0.0 & 0.0 & 0.0 & 0.0 & 0.0 & 0.0 & 3.4 & 3.7 & 3.8 & 2.6 & 1.4 \\
\hline $\begin{array}{l}\text { Separate payments for sugar } \\
\text { production }\end{array}$ & 5.1 & 4.6 & 1.8 & 1.2 & 1.4 & 1.3 & 1.1 & 0.0 & 0.0 & 0.0 & 1.4 \\
\hline CNDP for suckling cows & 0.0 & 0.0 & 0.0 & 6.4 & 0.0 & 0.0 & 0.0 & 0.0 & 0.0 & 0.0 & 0.8 \\
\hline $\begin{array}{l}\text { Decoupled CNDP for cattle } \\
\text { (since 2011) }\end{array}$ & 0.0 & 0.0 & 1.5 & 0.7 & 0.7 & 0.0 & 0.0 & 0.0 & 0.0 & 0.0 & 0.3 \\
\hline $\begin{array}{l}\text { Support for energy crops (since } \\
\text { 2007) }\end{array}$ & 0.0 & 0.0 & 0.0 & 0.0 & 0.0 & 0.2 & 0.4 & 0.7 & 0.6 & 0.3 & 0.2 \\
\hline Other & 0.0 & 0.0 & 0.0 & 0.0 & 0.0 & 0.0 & 0.0 & -8.9 & -9.3 & 0.0 & -1.1 \\
\hline
\end{tabular}

Source: authors' calculations based on Datu bāze ... (2016). 
Rates of the most significant direct payments in Latvia in the period $2005-2014$, EUR

\begin{tabular}{|l|c|c|c|c|c|c|c|c|c|c|}
\hline Kind of support/ year & 2005 & 2006 & 2007 & 2008 & 2009 & 2010 & 2011 & 2012 & 2013 & 2014 \\
\hline SAPS payments per ha & 26.18 & 31.45 & 36.38 & 46.38 & 55.61 & 63.50 & 76.12 & 79.00 & 86.16 & 99.06 \\
\hline CNDP for areas under crops, ha & 67.36 & 53.27 & 28.87 & 39.70 & 27.63 & - & - & - & - & - \\
\hline CNDP for areas under feed crops, ha & 15.50 & 12.62 & 11.21 & 9.02 & 6.63 & - & - & - & - & - \\
\hline CNDP for milk production, t & 16.35 & 28.56 & - & - & - & - & - & - & - & - \\
\hline Decoupled CNDP for milk production, t & - & - & 35.05 & 33.69 & 31.96 & 30.14 & 28.24 & 26.00 & 25.00 & 20.00 \\
\hline Decoupled CNDP for areas, ha & - & - & 25.57 & 30.73 & 35.68 & 32.31 & 26.00 & 19.00 & 19.00 & 15.00 \\
\hline $\begin{array}{l}\text { Decoupled CNDP for areas under crops, } \\
\text { ha }\end{array}$ & - & - & - & - & - & 36.31 & 28.98 & 28.00 & 28.00 & 23.00 \\
\hline Separate payments for sugar production, t & - & 9.96 & 12.01 & 14.68 & 15.87 & 11.94 & 7.95 & 7.89 & 7.88 & - \\
\hline
\end{tabular}

Source: authors' construction based on LR Zemkopības ministrija (2006, 2007, 2008, 2010, 2012, 2014, 2015).

\section{Analysis of kinds of support payments in Latvia}

Direct payments. In the period 2005 - 2014, FADN farms received 29 kinds of support as direct payments. The key kinds are presented in Table 1.

In the period of analysis, the most significant kinds of direct payments were SAPS payments with $46 \%$, CNDP for milk production within the limit of the quota (decoupled in 2007) - 13\%, CNDP for areas under crops and feed crops $-10 \%$, decoupled
CNDP for areas (from 2007) - 9\%, decoupled CNDP for areas under field crops (since 2010) - 6\% and separate payments for sugar production with $4 \%$ of the total amount of support. Besides, the share of SAPS considerably increased - from $34 \%$ (EUR 4.7 million in 2005) to $65 \%$ (EUR 15.9 million in 2014 ) - in the total amount of direct payments. In addition, financial discipline was applied in 2012 and 2013, which resulted in a decrease in the number

Table 3

Percentage distribution of support for rural development, the total amount of which exceeded EUR 500 thou. by kind of support for FADN farms in Latvia in the period $2005-2014$

\begin{tabular}{|l|c|c|c|c|c|c|c|c|c|c|c|}
\hline Indicators & 2005 & 2006 & 2007 & 2008 & 2009 & 2010 & 2011 & 2012 & 2013 & 2014 & Total \\
\hline Total & 100.0 & 100.0 & 100.0 & 100.0 & 100.0 & 100.0 & 100.0 & 100.0 & 100.0 & 100.0 & 100.0 \\
\hline Farm modernisation & 0.0 & 0.0 & 0.0 & 33.0 & 46.3 & 37.6 & 64.5 & 73.7 & 51.5 & 35.6 & 38.6 \\
\hline Less-favoured area support & 17.8 & 26.0 & 33.0 & 24.7 & 24.7 & 28.7 & 19.2 & 14.6 & 24.3 & 35.7 & 23.3 \\
\hline Structural funds & 52.3 & 30.1 & 16.7 & 7.7 & 0.0 & 0.0 & 0.0 & 0.0 & 0.0 & 0.0 & 10.2 \\
\hline Organic farming development & 4.6 & 10.1 & 8.3 & 9.0 & 9.7 & 12.9 & 9.5 & 7.7 & 12.1 & 17.6 & 9.7 \\
\hline Wind erosion reduction & 0.0 & 15.9 & 20.3 & 16.4 & 16.6 & 17.2 & 0.0 & 0.0 & 0.0 & 0.0 & 7.3 \\
\hline Meeting the EU standards & 15.0 & 14.4 & 18.1 & 5.7 & 0.0 & 0.4 & 0.0 & 0.0 & 0.0 & 0.0 & 4.7 \\
\hline Support to enterprises & 0.0 & 0.0 & 0.0 & 0.0 & 0.6 & 0.5 & 4.4 & 2.0 & 8.5 & 3.3 & 2.1 \\
\hline SAPARD (until 2006) & 8.4 & 0.9 & 0.0 & 0.0 & 0.0 & 0.0 & 0.0 & 0.0 & 0.0 & 0.0 & 1.0 \\
\hline $\begin{array}{l}\text { Infrastructure related to } \\
\text { agricultural and forestry } \\
\text { development and adaptation }\end{array}$ & 0.0 & 0.0 & 0.0 & 0.0 & 0.0 & 0.9 & 0.7 & 0.6 & 1.5 & 4.8 & 0.7 \\
\hline $\begin{array}{l}\text { Maintenance of biodiversity in } \\
\text { grassland }\end{array}$ & 0.6 & 1.1 & 1.0 & 0.9 & 0.7 & 0.8 & 0.6 & 0.4 & 0.7 & 1.0 & 0.7 \\
\hline $\begin{array}{l}\text { Support for semi-subsistance } \\
\text { farms }\end{array}$ & 0.5 & 0.3 & 2.3 & 2.0 & 1.0 & 0.3 & 0.1 & 0.1 & 0.1 & 0.1 & 0.6 \\
\hline $\begin{array}{l}\text { Areas with restrictions for the } \\
\text { purposes of environmental } \\
\text { protection }\end{array}$ & 0.8 & 1.2 & 0.4 & 0.4 & 0.3 & 0.4 & 0.3 & 0.2 & 0.4 & 0.6 & 0.5 \\
\hline $\begin{array}{l}\text { Introduction and promotion of } \\
\text { integrated horticulture (since } \\
\text { 2008) }\end{array}$ & 0.0 & 0.0 & 0.0 & 0.1 & 0.1 & 0.2 & 0.6 & 0.6 & 0.9 & 1.2 & 0.4 \\
\hline
\end{tabular}

Source: authors' calculations based on Datu bāze ... (2016). 


\section{Rates of the most significant rural development support payments in Latvia in the period $2005-2014$, EUR}

\begin{tabular}{|c|c|c|}
\hline Support measure & Period 2004-2006 & Period 2007-2013 \\
\hline $\begin{array}{l}\text { Less-favoured } \\
\text { area support }\end{array}$ & 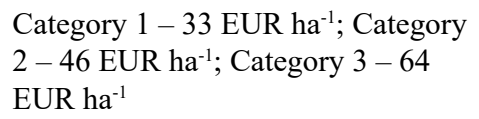 & $\begin{array}{l}\text { Category } 1 \text { - less than } 25 \text { EUR ha }^{-1} \text {; Category } 2 \text { - less than } 40 \\
\text { EUR ha }^{-1} \text {; Category } 3 \text { - less than } 58 \text { EUR ha }^{-1}\end{array}$ \\
\hline $\begin{array}{l}\text { Organic farming } \\
\text { development }\end{array}$ & $\begin{array}{l}\text { First transitional year - } 139 \text { EUR } \\
\text { ha }^{-1} \\
\text { Second transitional year }-139 \text { EUR } \\
\text { ha }^{-1} \\
\text { The farm is given an organic } \\
\text { farming certificate }-82 \text { EUR ha-1 }\end{array}$ & $\begin{array}{l}\text { Permanent meadows and pastures, nectar crops } 138 \text { EUR ha- } \\
{ }^{1} \text {; field crops on arable land, permanent grasses on arable land } \\
\text { and grassland for seed production, fallow land } 108 \mathrm{EUR} \mathrm{ha}^{-1} \text {; } \\
\text { potato, starch potato } 318 \mathrm{EUR} \mathrm{ha}^{-1} \text {; vegetables (incl. spice } \\
\text { crops) and household gardens } 357 \mathrm{EUR} \mathrm{ha}^{-1} \text {; fruit trees and } \\
\text { berry bushes } 419 \mathrm{EUR}^{-1} \mathrm{~h}^{-1}\end{array}$ \\
\hline $\begin{array}{l}\text { Wind erosion } \\
\text { reduction }\end{array}$ & $\begin{array}{l}\text { Per ha of green area (except } \\
\text { permanent meadows and pastures): } \\
\text { nitrite-sensitive territories }-23 \text { EUR } \\
\text { ha }^{-1} \text {; other areas of Latvia }-40 \text { EUR } \\
\text { ha }^{-1}\end{array}$ & Not available. \\
\hline
\end{tabular}

Source: authors' construction based on MK noteikumi...(2004); LAP (2007 - 2013).

of eligible support payments (above EUR 5000 and EUR 300000) and in the total amount disbursed - by EUR 2.2 and 2.3 million respectively, and by EUR 4.5 million in the entire period. Rates of the key kinds of direct payments are presented in Table 2. SAPS rates increased 3.8 times in the period 2005 - 2014; besides, the payments for particular crops were replaced by decoupled (historical) payments, which indicate changes in the CAP.

Rural development support payments. In the period 2005 - 2014, FADN farms received 24 kinds of financial support for rural development. The key kinds are shown in Table 3 . In the period of analysis, the most significant kinds of support for rural development were as follows: investment support under the RDP 2007 - 2013 with 39\%, less-favoured area support (less-favoured areas and areas with restrictions for the purposes of environmental protection under the RDP $2004-2006$ and 'Payments to farmers in areas with handicaps other than mountain areas' under the RDP $2007-2013$ ) $-23 \%$, structural funds $-10 \%$, support for organic farming development under the RDP $2007-2013-10 \%$, wind erosion reduction $-7 \%$ and meeting the EU standards (support measures under the RDP $2004-2006$ ) with 5\% of the total amount. The greatest amount of support for rural development was reported in 2012, at EUR 32.4 million, of which investment support under the RDP 2007 - 2013 comprised $74 \%$ of the total. FADN farms received the smallest amount of support for rural development in 2014 - EUR 13.4 million, of which less-favoured area support accounted for $36 \%$ of the total.

The rates of area-based support payments for rural development per hectare of farmland are shown in Table 4, while the key eligibility criteria for investment support are presented in Table 5.

In the period 2007 - 2013 in Latvia, the rates of less-favoured area support payments decreased, while

Table 5

Key eligibility criteria for the most significant support measures for investment in rural development in Latvia in the period $2005-2014$, EUR

\begin{tabular}{|c|c|c|c|c|}
\hline Eligibility criteria & SAPARD & SF & Meeting the standards & EAFRD \\
\hline Purchase of new machinery & $\mathrm{x}$ & $x^{*}$ & \multirow{5}{*}{$\begin{array}{l}\text { Construction of manure storage facilities; meeting the hygienic } \\
\text { standards in milk production; meeting the standards for } \\
\text { cowsheds to guarantee milk hygiene; reconstruction of cages } \\
\text { to ensure the welfare of laying hens; equipping an artificial } \\
\text { ventilation system with an alert device and the establishment } \\
\text { of an emergency ventilation system; construction or } \\
\text { reconstruction of a water supply system at livestock sheds; } \\
\text { construction of cages for young livestock; establishment of } \\
\text { farrowing boxes for sows and pigsties for weaned piglets. }\end{array}$} & $\mathrm{x}$ \\
\hline Purchase of new equipment & $\mathrm{x}$ & $\mathrm{x}$ & & $\mathrm{x}$ \\
\hline $\begin{array}{l}\text { Construction, } \\
\text { reconstruction, renovation }\end{array}$ & $\mathrm{x}$ & $\mathrm{x}$ & & $\mathrm{x}$ \\
\hline $\begin{array}{l}\text { Investment in permanent } \\
\text { crops }\end{array}$ & - & $\mathrm{x}$ & & - \\
\hline $\begin{array}{l}\text { Purchase of breeding } \\
\text { livestock }\end{array}$ & $\begin{array}{l}\text { Milk and } \\
\text { meat }\end{array}$ & $x^{*}$ & & - \\
\hline
\end{tabular}

*not included in eligible costs of projects submitted from 2006 onwards

Source: authors' construction based on MK noteikumi...(2004); LAP (2007 - 2013); Upite (2010). 
Table 6

Percentage distribution of support for rural development, the total amount of which exceeded EUR 500 thou. by kind of support for FADN farms in Latvia in the period 2005 - 2014

\begin{tabular}{|c|c|c|c|c|c|c|c|c|c|c|c|}
\hline Indicators & 2005 & 2006 & 2007 & 2008 & 2009 & 2010 & 2011 & 2012 & 2013 & 2014 & Total \\
\hline Total & 100.0 & 100.0 & 100.0 & 100.0 & 100.0 & 100.0 & 100.0 & 100.0 & 100.0 & 100.0 & 100.0 \\
\hline Payments for cows held & 15.2 & 9.4 & 11.8 & 22.1 & 62.7 & 20.3 & 41.5 & 0.0 & 0.0 & 24.1 & 19.1 \\
\hline $\begin{array}{l}\text { Support for establishment of } \\
\text { a herdbook and assessment of } \\
\text { productivity data: dairy cows }\end{array}$ & 0.0 & 0.0 & 0.0 & 20.2 & 0.0 & 38.9 & 0.0 & 77.4 & 49.4 & 30.8 & 18.9 \\
\hline $\begin{array}{l}\text { Promotion of investment in } \\
\text { agriculture - partially subsidised } \\
\text { loans }\end{array}$ & 13.1 & 8.0 & 12.6 & 25.0 & 22.6 & 11.5 & 17.7 & 7.1 & 9.6 & 8.0 & 13.0 \\
\hline $\begin{array}{l}\text { Support for investment in the } \\
\text { agriculture }\end{array}$ & 29.5 & 19.4 & 21.8 & 0.0 & 0.0 & 0.0 & 0.0 & 0.0 & 0.0 & 0.0 & 8.9 \\
\hline $\begin{array}{l}\text { Compensation for losses caused } \\
\text { by agro-climatic conditions }\end{array}$ & 7.0 & 42.2 & 0.0 & 0.0 & 0.0 & 1.1 & 0.0 & 0.0 & 0.1 & 0.0 & 8.4 \\
\hline $\begin{array}{l}\text { Support for establishment of } \\
\text { a herdbook and assessment of } \\
\text { productivity data: sows }\end{array}$ & 0.0 & 0.0 & 0.0 & 0.0 & 0.0 & 0.0 & 0.0 & 0.0 & 29.8 & 27.9 & 6.3 \\
\hline $\begin{array}{l}\text { Identification of genetic quality: } \\
\text { in sows }\end{array}$ & 3.8 & 2.8 & 24.0 & 7.9 & 0.0 & 0.0 & 0.0 & 0.0 & 0.0 & 0.0 & 5.1 \\
\hline Purchase of breeding livestock & 7.4 & 4.1 & 12.2 & 0.0 & 0.0 & 0.0 & 0.0 & 0.0 & 0.0 & 0.0 & 3.1 \\
\hline $\begin{array}{l}\text { Support for livestock breeding } \\
\text { and raising in pig farming: piglet }\end{array}$ & 3.8 & 3.6 & 4.9 & 4.0 & 0.0 & 0.0 & 0.0 & 0.1 & 0.0 & 0.3 & 2.1 \\
\hline $\begin{array}{l}\text { Education, science and } \\
\text { information }\end{array}$ & 5.8 & 0.8 & 2.5 & 6.6 & 0.4 & 0.0 & 0.0 & 0.0 & 0.0 & 0.0 & 1.6 \\
\hline $\begin{array}{l}\text { Support for livestock breeding } \\
\text { and raising in pig farming: sows }\end{array}$ & 0.0 & 0.0 & 0.0 & 3.1 & 0.0 & 3.8 & 24.5 & 0.0 & 0.0 & 0.0 & 1.5 \\
\hline $\begin{array}{l}\text { Support for promotion of } \\
\text { investment in agricultural and } \\
\text { enhancement of technological } \\
\text { resources for investment in } \\
2012 / 2013\end{array}$ & 0.0 & 0.0 & 0.0 & 0.0 & 0.0 & 0.0 & 0.0 & 10.4 & 0.0 & 0.0 & 0.9 \\
\hline $\begin{array}{l}\text { Support for establishment of } \\
\text { a herdbook and assessment of } \\
\text { productivity data: meat cows }\end{array}$ & 0.0 & 0.0 & 0.0 & 0.0 & 0.0 & 0.0 & 0.0 & 0.0 & 4.9 & 3.3 & 0.9 \\
\hline $\begin{array}{l}\text { Support for integrated production } \\
\text { of permanent crops }\end{array}$ & 0.0 & 1.0 & 1.2 & 1.7 & 1.6 & 4.0 & 0.0 & 0.0 & 0.0 & 0.0 & 0.8 \\
\hline $\begin{array}{l}\text { Support for livestock breeding } \\
\text { and raising in pig farming: boars }\end{array}$ & 0.0 & 0.0 & 0.0 & 0.2 & 6.1 & 0.1 & 0.0 & 0.0 & 0.0 & 0.0 & 0.7 \\
\hline Other & 14.4 & 8.7 & 9.0 & 9.3 & 6.6 & 20.4 & 16.3 & 5.0 & 6.1 & 5.7 & 8.8 \\
\hline
\end{tabular}

Source: authors' calculations based on Datu bāze ... (2016).

the rates of support payments for organic farming development diverged across crops.

National support. The percentage distribution of the key kinds of national support is shown in Table 6 . In the period $2005-2014$, there were 73 kinds of nation financial support for FADN farms. In the same period, the most significant kinds of support for FADN farms were as follows: payments for cows held - slightly more than $19 \%$, support for establishment of a herdbook and assessment of productivity data: dairy cows - almost $19 \%$, promotion of investment in agriculture - partially subsidised loans $-13 \%$, support for investment in the agricultural industry (in $2005-2007$ ) - 9\%, compensation for losses caused by agro-climatic conditions - $8 \%$, support for establishment of a herdbook and assessment of productivity data for sows $-6 \%$, identification of genetic quality in sows $-5 \%$ and purchase of breeding livestock in a foreign or the Latvian market with $3 \%$ of the total amount of national support funding. The greatest amount received by the FADN farms was reported in 2006 - EUR 13.8 million, of which EUR 
5.8 million or $42 \%$ were compensations for losses caused by agro-climatic conditions.

3. Relationships between the amounts of support payments and other agricultural and farm performance indicators

A correlation analysis that explores the strength of relationships between a dependent variable $\mathrm{x}_{\mathrm{n}}$ (support payments) and several independent variables $y_{n}$ was done to identify the strength of relationships between various indicators of farm performance (Arhipova \& Balina, 2000). Three dependent variables were taken: $\mathrm{x}_{1}=$ total amount of support payments for FADN farms, mln. EUR; $x_{2}=$ area-based support payments for FADN farms, mln. EUR; $x_{3}=$ support payments for investment for FADN farms, mln. EUR, and a correlation between the mentioned three variables and selected other farm indicators was identified for

Table 7

Strength of the relationships between the amounts of support payments and other indicators for FADN farms in Latvia in the period 2005 - 2014 (correlation coefficient value r)

\begin{tabular}{|c|c|c|c|c|}
\hline \multirow[t]{2}{*}{ Indicators } & \multicolumn{2}{|c|}{$\begin{array}{l}\text { Total support, } \\
\text { mln. EUR }\left(\mathrm{x}_{1}\right)\end{array}$} & \multicolumn{2}{|c|}{$\begin{array}{c}\text { Total area payments, } \\
\text { mln. EUR }\left(\mathrm{x}_{2}\right)\end{array}$} \\
\hline & $r$ & Sig. & $r$ & Sig. \\
\hline \multicolumn{5}{|c|}{ At least one indicator shows a strong correlation $([\mathrm{r}]>0.8)$} \\
\hline Agricultural exports, mln. EUR & 0.884 & 0 & 0.796 & 0.01 \\
\hline Total area payments for agriculture, mln. EUR & 0.873 & 0 & 0.876 & 0 \\
\hline Area under maize, thou. ha & 0.84 & 0 & 0.827 & 0 \\
\hline Area under potato (CSB data), thou. ha & -0.806 & 0 & -0.677 & 0.03 \\
\hline Long-term investment by FADN farms, mln. EUR & 0.889 & 0 & 0.837 & 0 \\
\hline Revenue earned by FADN farms, mln. EUR & 0.82 & 0 & 0.749 & 0.01 \\
\hline Revenue from grain earned by FADN farms, mln. EUR & 0.839 & 0 & 0.637 & 0.05 \\
\hline Revenue from vegetables earned by FADN farms, mln. EUR & 0.694 & 0.03 & 0.834 & 0 \\
\hline Production costs for FADN farms, mln. EUR & 0.869 & 0 & 0.814 & 0 \\
\hline Milk sold (CSB data), thou. $\mathrm{t}$ & 0.879 & 0 & 0.833 & 0 \\
\hline Wheat produced by FADN farms, thou. $t$ & 0.818 & 0 & 0.725 & 0.02 \\
\hline Fixed asset depreciation for FADN farms, mln. EUR & 0.868 & 0 & 0.788 & 0.01 \\
\hline \multicolumn{5}{|c|}{ A medium-strong relationship $([\mathrm{r}]$ is $>0.5$, but $<0.8)$} \\
\hline Area payments received by FADN farms, mln. EUR & 0.797 & 0.01 & & \\
\hline Total support payments made by the RSS, mln. EUR & 0.772 & 0.01 & 0.611 & 0.06 \\
\hline UAA (CSB data), mln. ha & 0.73 & 0.01 & 0.764 & 0.01 \\
\hline Area of pastures and meadows (CSB data), thou. ha & 0.794 & 0.01 & 0.667 & 0.03 \\
\hline Area under permanent crops (CSB data), thou. ha & -0.775 & 0.01 & & \\
\hline Area of pastures and meadows on arable land (CSB data), thou. ha & 0.792 & 0.01 & 0.667 & 0.03 \\
\hline Arable land area (CSB data), thou. ha & 0.628 & 0.05 & 0.692 & 0.03 \\
\hline Revenue from rapeseed earned by FADN farms, mln. EUR & 0.783 & 0.01 & & \\
\hline Revenue from legumes earned by FADN farms, mln. EUR & 0.565 & 0.09 & 0.725 & 0.02 \\
\hline Revenue from other agricultural activities earned by FADN farms, mln. EUR & -0.715 & 0.02 & & \\
\hline Revenue from feed production earned by FADN farms, mln. EUR & 0.798 & 0.02 & 0.722 & 0.02 \\
\hline Revenue from milk earned by FADN farms, mln. EUR & 0.788 & 0.01 & 0.724 & 0.02 \\
\hline Revenue from cattle earned by FADN farms, mln. EUR & 0.775 & 0.01 & 0.724 & 0.02 \\
\hline Revenue from pigs earned by FADN farms, mln. EUR & 0.603 & 0.07 & 0.7 & 0.02 \\
\hline Revenue from poultry earned by FADN farms, mln. EUR & -0.689 & 0.03 & & \\
\hline Revenue from egg production earned by FADN farms, mln. EUR & -0.517 & 0.12 & -0.696 & 0.02 \\
\hline Agricultural work units on FADN farms, employed individuals & -0.697 & 0.02 & & \\
\hline Milk output (CSB data), thou. $t$ & 0.682 & 0.03 & 0.793 & 0.01 \\
\hline
\end{tabular}

Source: authors' calculations based on CSB data (2016a; 2016b; 2016c, 2016d). 
the period 2005-2015. When performing a correlation analysis, the tool IBM SPSS Statistics (Version 22) was exploited and a correlation matrix was computed. Since the correlation matrix is symmetric relative to its diagonal, only the values placed above and under the diagonal have to be computed. The main results are summarised in Table 4. The total amount of support payments and the amount of area-based support payments have affected the following key agricultural indicators: the value of agricultural exports, the utilised agricultural area, areas under certain crops and revenue from the key kinds of agricultural production. The analysis has shown that CAP direct payments as a whole have been effective in pursuing a more equitable distribution of farm household income among the farm household population (Severini \& Tantari, 2015). Since the support payments (both the total amount of support payments and the amount of area-based support payments) strongly correlated with the total production cost for FADN farms, the main cost items (seeds, fertilisers, plant protection products, purchased feed, maintenance of machinery and equipment, fuel and lubricants, depreciation, paid labour and land rent) also demonstrated strong correlations. As the amount of support payments increased, a few farm indicators decreased (areas under potato and permanent crops, revenue from other agricultural activities, output of poultry meat and eggs as well as agricultural work units). However, the amount of support payments for investment for FADN farms, $\mathrm{mln}$. EUR, $\left(\mathrm{x}_{3}\right)$ had a strong correlation $(0.997$ at sig.0.00) only with fixed asset depreciation for the FADN farms.

\section{Conclusions}

1. Support payments play an important role in the performance of farms in Latvia. In the period 2005-2014, the total amount of financial support equalled EUR 4.3 billion, of which EUR 520 million or $12 \%$ were received by approximately 1000 FADN farms. The amount of support for FADN farms ranged from EUR 41 million in 2005 to EUR 64 million in 2012. In the period of analysis, FADN farms received three key kinds of support: direct payments $-47 \%$, support for rural development $-39 \%$ and national support with $14 \%$ of the total.

2. The detailed analysis of the key kinds of support revealed that:

- there were 29 kinds of direct payments in the period 2005-2014, while the most significant one was SAPS payments, accounting for $46 \%$ of the total; besides, their rates per ha increased 3.8 times. The other significant kinds were as follows: CNDP for milk production with $13 \%$, CNDP for areas under crops and feed crops $-9 \%$ and decoupled CNDP for areas with $15 \%$;

- among the kinds of support for rural development (totally 24), the most significant ones were as follows: investment support with $39 \%$ of the total in the period $2007-2013$ and environment-related support payments with $45 \%$;

- the significance of national subsidies decreased, yet their diversity (74 kinds) indicated that by means of this support the country sought to solve problems for which no EU support was available.

3. The correlation analysis showed that the total amount of support payments and the amount of area-based support payments affected the key agricultural indicators - the value of agricultural exports, the utilised agricultural area, areas under certain crops, and revenues from the key kinds of agricultural production as well as key cost items.

\section{References}

1. Datu bāze par SUDAT saimniecībām izmaksāto atbalstu (2016). Nepublicēts resurss (Database on financial support granted to FADN farms. Unpublished resource). (in Latvian).

2. Arhipova, I., \& Balina, S. (2000). Statistika ar Microsoft Excel ikvienam (Statistics with Microsoft Excel for Everyone). Riga: Datorzinību centrs, 136 p. (in Latvian).

3. Burnya, Ph., \& Terrones Gavira, F. (2015). Gainers and Losers of the Implementation of the New Common Agricultural Policy in Wallonia. Agriculture and Agricultural Science Procedia. Vol. 7. pp. 50 - 53.

4. Centrālā statistikas pārvalde (CSB) (2016a). LSSA13_II03. LAUKU SAIMNIECĪBU GRUPĒJUMS PĒC IZMANTOTĀS LAUKSAIMNIECİBĀ IZMANTOJJAMĀS ZEMES 2013. gadā (Central Statistical Bureau. Agricultural Holdings by Utilised Agricultural Area in 2013). Retrieved September 10, 2016, from: http://data.csb.gov.lv/pxweb/lv/lauks/lauks_ikgad_laukstrukt_13_2.zeme/LSS13_II03.px/table/ tableViewLayout 1/?rxid=6cc3d9ab-cf2b-4b29-97da-47ba3ef61152. (in Latvian).

5. Centrālā statistikas pārvalde (CSB) (2016b). LSS01. Lauku saimniecību skaits un zemes platības statistiskajos reǵionos 2005. gadā (Central Statistical Bureau. Number of farms and land area by statistical region in 2005). Retrieved September 12, 2016, from: http://data.csb.gov.lv/pxweb/lv/lauks/lauks ikgad_laukstrukt/001_saimn_zeme_LV.px/table/tableViewLayout1/?rxid=cdcb978c-22b0-416a-aaccaa650 $\overline{\mathrm{d} 3} \mathrm{e} 2 \mathrm{ce} 0$. (in Latvian). 
6. Centrālā statistikas pārvalde (CSB) (2016c). LIG0116. Piena iepirkums un iepirktā piena kvalitāte (Central Statistical Bureau. Purchase of milk and milk quality). Retrieved September 8, 2016, from: http://data. csb.gov.lv/pxweb/lv/lauks/lauks_ikgad__01Lauks_visp/LI0116.px/?rxid=cdcb978c-22b0-416a-aaccaa650d3e2ce0. (in Latvian).

7. Centrālā statistikas pārvalde (CSB) (2016d). LLG008. Galveno lopkopības produktu ražošana (Central Statistical Bureau. Output of Principal Livestock Products). Retrieved September 8, 2016, from: http:// data.csb.gov.lv/pxweb/lv/lauks/lauks_ikgad_05Lopk/LL0080.px/?rxid=cdcb978c-22b0-416a-aacc aa650d3e2ce0. (in Latvian).

8. European Commission (2017). Farm Accountancy Data Network (FADN). Retrieved January 24, 2017, from: https://ec.europa.eu/agriculture/fadn_lv.

9. Fragoso, R., Marques, C., Lucas, M.R., Martins, M.B., \& Jorge, R. (2011). The Economic Effects of Common Agricultural Policy on Mediterranean Montado/dehesa Ecosystem. Journal of Policy Modeling, Vol. 33, pp. $311-327$.

10. Latvijas lauku attīstības programma 2007. - 2013. gads (LAP 2007 - 2013). Zemkopibas ministrija (Rural Development Programme of Latvia 2007 - 2013 (RDP 2007 - 2013) Ministry of Agriculture), Riga. 464 p. Retrieved October 4, 2016, from: https://www.zm.gov.lv/public/files/CMS_Static_Page_Doc/00/00/00/69/57/ LAP_2007-213_versija_15_clean.pdf. (in Latvian).

11. Latvijas Valsts Āgrārās ekonomikas institūts (LVAEI) (2006). Lauku saimniecības darba ekonomiskās analīzes rezultāti 2005 (SUDAT) (Latvian State Institute of Agrarian Economics. Agricultural Holdings. Results of Economic Analysis 2005 (FADN)), Riga, pp. 82 - 111. (in Latvian).

12. Latvijas Valsts Agrārās ekonomikas institūts (LVAEI) (2014). Lauku saimniecības darba ekonomiskās analīzes rezultāti 2013 (SUDAT) (Latvian State Institute of Agrarian Economics. Agricultural Holdings. Results of Economic Analysis 2013 (FADN)), Riga, 70 p. (in Latvian).

13. Lauku atbalsta dienests (2016a). Izmaksātā atbalsta apjoms un struktūra, milj.LVL (Rural Support Service. Amount and Percentage Distribution of Financial Support Paid). Retrieved September 16, 2016, from: www.lad.gov.lv/ files/kopsavilkums_par_lad_veikt_izm_2004_2013_final.pptx. (in Latvian).

14. Lauku atbalsta dienests (2016b). LAD izmaksātais finansējums, milj. EUR. (Rural Support Service. Amount and Percentage Distribution of Financial Support Paid). Retrieved September 18, 2016, from: http://www.lad.gov.lv/ files/lad_izmaksas_2010_2014.pdf. (in Latvian).

15. Lowe, P., Buller, H., \& Ward, N. (2002). Setting the Agenda? British and French Approaches to the Second Pillar of the Common Agricultural Policy. Journal of Rural Studies, Vol. 18, pp. $1-17$.

16. LR Zemkopības ministrija (2006). Latvijas lauksaimniecība un lauki 2006 (Ministry of Agriculture of the Republic of Latvia. Agriculture and Rural Areas of Latvia 2006), 151 p. (in Latvian).

17. LR Zemkopības ministrija (2007). Latvijas lauksaimniecība un lauki 2007 (Ministry of Agriculture of the Republic of Latvia. Agriculture and Rural Areas of Latvia 2007), 152 p. (in Latvian).

18. LR Zemkopības ministrija (2008). Latvijas lauksaimniecība un lauki 2008 (Ministry of Agriculture of the Republic of Latvia. Agriculture and Rural Areas of Latvia 2008), 116 p. (in Latvian).

19. LR Zemkopības ministrija (2010). Latvijas lauksaimniecība un lauki 2010 (Ministry of Agriculture of the Republic of Latvia. Agriculture and Rural Areas of Latvia 2010), 110 p. (in Latvian).

20. LR Zemkopibas ministrija (2012). Latvijas lauksaimniecība 2012 (Ministry of Agriculture of the Republic of Latvia. Agriculture of Latvia 2012), 133 p. (in Latvian).

21. LR Zemkopibas ministrija (2014). Latvijas lauksaimniecība 2014 (Ministry of Agriculture of the Republic of Latvia. Agriculture of Latvia 2014), 156 p. (in Latvian).

22. LR Zemkopības ministrija (2015). Latvijas lauksaimniecība 2015 (Ministry of Agriculture of the Republic of Latvia. Agriculture of Latvia 2015), 156 p. (in Latvian).

23. LR Zemkopības ministrija (2017). Lauku saimniecību datu uzskaites tīkls (SUDAT) (Ministry of Agriculture of the Republic of Latvia. Farm Accountancy Data Network (FADN)). Retrieved January 27, 2017, from: https://www. zm.gov.lv/zemkopibas-ministrija/statiskas-lapas/lauku-saimniecibu-datu-uzskaites-tikls-sudat ?id=1569\#jump. (in Latvian).

24. Ministru kabineta (MK) noteikumi Nr.1002 (2004). Kārtība, kādā ieviešams programmdokuments 'Latvijas Lauku attīstības plāns Lauku attīstības programmas īstenošanai 2004. - 2006. gadam’ (Cabinet Regulation No. 1002. Procedure of Introducing the Programming Document 'Rural Development Plan of Latvia for Implementing the Rural Development Programme 2004 - 2006'), 'Latvijas Vēstnesis', 193 (3141), 30 November 2004, Riga, 101 p. (in Latvian).

25. Raggi, M., Sardonini, L., \& Viaggi, D. (2013). The Effects of the Common Agricultural Policy on Exit Strategies and Land Re-allocation. Land Use Policy, Vol. 31, pp. 114 - 125. 
26. Severini, S., \& Tantari, A. (2015). The Distributional Impact of Agricultural Policy Tools on Italian Farm Household Incomes. Journal of Policy Modeling, Vol. 37, pp. $124-135$.

27. Upīte, I. (2010). Ieguldījumu atbalsta izmantošana Latvijas lauksaimniecībā. Promocijas darbs (Use of Investment Support in Latvian Agriculture), Jelgava, 222 p. (in Latvian).

28. Watts, D., Ilbery, B., Maye, D., \& Holloway, L. (2009). Implementing Pillar II of the Common Agricultural Policy in England: Geographies of the Rural Enterprise Scheme and Processing and Marketing Grant. Land Use Policy. Vol. 26. pp. $683-694$. 